\title{
Assessment and Evaluation of Student Learning Through a Project-Based Assignment on Note by Note Cooking
}

\author{
Róisín M. Burke ${ }^{a^{*}}$ AND PAUline DANAHER ${ }^{\mathrm{a}}$ \\ a School of Culinary Arts and Food Technology, Technological University (TU) Dublin, City Campus, Ireland \\ ${ }^{*}$ Corresponding author \\ roisin.burke@tudublin.ie \\ TEL.: +353-1-4024346
}

Received: 30 October 2018; Published online: 18 October 2020 (heck for updates

Invited paper from the 5th International ISEKI Food Conference - ISEKI Food 2018 - The Food System

Approach - New challenges for Education, Research and Industry

\begin{abstract}
Many innovative teaching and learning methods are used in higher level education including projectbased learning (PBL). Since 2012 a PBL assignment project has been undertaken by master students of the Advanced Molecular Gastronomy module at Technological University Dublin (TU Dublin). The aim is to stimulate student learning and creativity by using Note by Note cooking in a PBL assignment while at the same time complying with the requirements of the annual International Note by Note contest which is held in Paris, France. Direct and indirect assessment methods were used to assign individual grades and to gather student feedback about the module. The direct methods were both formative and summative. The indirect method used was a student feedback questionnaire. Results to date (2012-2019) showed that $92 \%$ of learners successfully passed the module. However, further evaluation of individual assessment results revealed that most students achieved higher scores for finding and using resources, asking further questions and developing their own answers than for analysing, synthesising and evaluating information $(\mathrm{P} \leq 0.01)$. Overall students were happy with the module content and said that they learnt about Note by Note cooking, chemical compounds, researching, independentthinking and perseverance. In future students should carry out a more in-depth analysis, synthesis and evaluation of information.
\end{abstract}

Keywords: Molecular Gastronomy; Project-based learning; Note by Note Cooking

\section{Introduction}

Food science education has undergone a paradigm shift from a delivery of knowledge in a traditional lecture and laboratory system to a more inquiry-based and discovery process (Iwaoka, Britten \& Dong, 1996 cited in Shewfelt (2012)). Traditional style laboratory practicals often leave little room for creativity or contextualisation, and are usually a verification of a known quantity or a testing of a theory that has been presented in lectures (Mc Donnell,
O'Connor \& Seery, 2007). Innovations such as the use of journals, team-based learning, simulations, problem-based studies, and other techniques engage students more actively in the learning process (Shewfelt, 2012).

Many terms are used for learning through inquiry, including 'inquiry-based learning', 'guided-inquiry', 'problem-based learning' and 'research-based teaching' (Spronken-Smith \& Walker, 2010). Project-based learning (PBL) uses instructional strategies that are intended to engage students in authentic, "real world" tasks 
to enhance learning. It can be an individual or group activity that goes on over a period of time, resulting in a product, presentation, or performance (Donnelly \& Fitzmaurice, 2005). These authors explain that PBL typically has a timeline and milestones, and other aspects of formative evaluation as the project proceeds. Students engage in deeper learning, high-level reading and increased motivation (Bell, 2010). One study, carried out over the course of three years in Britain, showed that three times as many PBL students achieved the highest possible grade in mathematics in the national exam than the students at a traditional school. Students at the PBL school were equally able to answer procedural questions that used formulas, but they were superior in answering applied and conceptual problems (Boaler, 1999). In the United States of America, Thomas (2000) noted that studies conducted on the effectiveness of using PBL over three years in a school in Iowa showed that reading gains "ranged from $15 \%$ in one school to over $90 \%$ in two other schools while the district average remained the same", and in Boston, eight graders exhibited the second highest scores in the district on the Stanford 9 open ended reading assessment. Similar findings in Portland, Maine, led to a conclusion that a middle school using a PBL approach showed significant increases in all achievement areas on the Maine educational assessment test for cognitive development after only one year of using the PBL approach. The gains made by this school were three to ten times higher than the state average. Similar improvements were reported for schools in Colorado, Illinois, Georgia, Cincinnati, Ohio, Memphis, Tennessee, and New York City. Doppelt (2003) states that students who took part in PBL were motivated to learn their discipline and willing to work on their projects for a longer time. In another study, attendance was found to be higher in PBL schools (Thomas, 2000).

The process used in PBL can replicate the commonly used systemic approach to resolving problems or meeting challenges that are encountered in life and career. Historically the project-based approach has been widely used in the science classroom (Krajcik \& Shin, 2014) and as a result, the findings from evaluations of science orientated PBL has helped to build evidence for the efficacy of the design principles (Condliffe, Visher, Bangser, Drohojowska \& Saco, 2016).

Molecular gastronomy, a sub-discipline of food science, has since 2009 been established as a subject discipline at the Technological University Dublin (abbreviated as TU Dublin and formerly known as the Dublin Institute of Technology) in Ireland (Burke \& Danaher, 2018; Burke, Danaher \& Traynor, 2012). The culinary activity called "Note by Note" cooking is an application of molecular gastronomy (MG) and it makes an important contribution to the fight against spoilage, while sparing water, energy, foodstuffs, and taking care of the environment (This, 2017). In this type of cooking, traditional food ingredients are not used to make dishes but pure compounds or mixtures of pure compounds are used (Burke \& Danaher, 2016; This, 2014). They are assembled by the chef to design the shapes, colours, tastes, odours, temperatures, trigeminal stimulation, consistencies, nutritional aspects, and more, of the desired dish (This, 2017). The project-based principles for the Note by Note assignment are shown in Figure 1.

This paper provides results and discussion on the assessment of individual students and an evaluation of the achievement of the module learning outcomes.

\section{Methodology}

\subsection{Student Group}

The student group were TU Dublin students from the taught M.Sc. programme in Culinary Innovation and Food Product Development who took the postgraduate module in Advanced Molecular Gastronomy (approximately 13 in each academic year since 2012/2013 until the present time, 2018/2019).

\subsection{Curriculum}

The module ran for three consecutive hours, each week, over twelve weeks in one semester of the academic year (36 hours class contact). It was delivered by a teaching team of a culinary sci-

IJFS | October 2020 | Volume 9 | pages 282-294 


\begin{tabular}{|l|}
\hline - The task and project brief \\
\hline - Research \\
\hline - Planning \\
\hline - Improve recipe(s) \\
\hline - Evaluate \\
\hline
\end{tabular}

Figure 1: Stages in the Note by Note project-based learning assignment

ence lecturer (theory and practicals) and a culinary arts lecturer (practicals).

The main features of the postgraduate module were theoretical lectures, practical kitchen classes, and a PBL assignment that was conducted during the last five classes $(5 \times 3$ hours $=15$ hours). The curriculum included theory lectures about the chemical reactivity of pure compounds such as sodium alginate and calcium chloride. Toxicological and nutritional facts relating to chemical compounds used for Note by Note cooking were presented and discussed. Students were asked to check information from the Food Safety Authority of Ireland and the European Union regarding the maximum permitted daily intake levels of compounds that they were using in their Note by Note dishes. Lectures and practicals were focused on the chemical and physical properties of pure compounds such as gelling agents, liquid nitrogen and dry ice, scientific testing of culinary precisions, demonstration of how a Note by Note dish is made and the creation of an entirely new food using Note by Note cooking. Culinary precisions are all the technical additions that are not part of the operating protocol of a recipe; e.g. the operating protocol for an orange jam (marmalade) recipe involves slices of oranges plus sugar plus heat and the culinary precision is that it is sometimes 'said' that you have to cook until a drop of the liquid forms a gel on a cold plate (Burke, This \& Kelly, 2016).

\subsection{Assessment and Evaluation of the assignment}

Breslow (2007) emphasises that best practice in educational research dictates triangulating data. If several different sources of data are used, it increases the probability that the findings present an accurate picture. The essential elements of the assignment were identified as (1) finding and using resources, asking further questions, developing answers and (2) analysing, synthesising and evaluating information. These essential elements were then matched against the learning outcomes of the module and assessment methods. Direct and indirect assessment methods were used in this study and are outlined in Table 1.

\section{Direct assessment}

Summative assessment is product-oriented and assesses the final product, whereas formative assessment focuses on the process toward com- 
Evaluation of a project-based Note by Note assignment $\mid 285$

Table 1: Learning outcomes matched to essential elements of the PBL exercise and corresponding assessment methods

\begin{tabular}{|c|c|c|c|}
\hline \multirow[b]{2}{*}{ Essential element } & \multirow{2}{*}{ Learning Outcome } & \multicolumn{2}{|c|}{ Assessment } \\
\hline & & Formative & Summative \\
\hline $\begin{array}{l}\text { 1. Finding and us- } \\
\text { ing resources, asking } \\
\text { further questions, de- } \\
\text { veloping their own an- } \\
\text { swers (Dahm, 2014) }\end{array}$ & $\begin{array}{l}\text { 2. Produce a novel } \\
\text { and innovative } \\
\text { dish/cocktail using } \\
\text { ingredients and tech- } \\
\text { niques associated with } \\
\text { applications of Mo- } \\
\text { lecular Gastronomy. } \\
\text { 3. Develop new skills } \\
\text { to a high level through } \\
\text { using novel techniques } \\
\text { such as Note by Note } \\
\text { cooking. }\end{array}$ & Informal observation & $\begin{array}{l}\text { Sections } 1,2,7 \text { : Liter- } \\
\text { ature search relating } \\
\text { to Molecular Gastro- } \\
\text { nomy, Note by Note } \\
\text { cooking and the spe- } \\
\text { cific theme for the as- } \\
\text { signment. Aim(s) of } \\
\text { assignment. } \\
3,8 \text { : Materials, } \\
\text { Equipment, Meth- } \\
\text { ods/Recipes. Record- } \\
\text { ing kitchen trials and } \\
\text { improvements to be } \\
\text { made. } \\
\text { International competi- } \\
\text { tion }\end{array}$ \\
\hline \multirow[t]{2}{*}{$\begin{array}{l}2 . \quad \text { Analysis, syn- } \\
\text { thesis and evaluation } \\
\text { of information (Dahm, } \\
2014 \text { ) }\end{array}$} & $\begin{array}{l}\text { 1. Critically evaluate } \\
\text { the fundamental sci- } \\
\text { entific theories of Mo- } \\
\text { lecular Gastronomy. }\end{array}$ & In formal observation & Academic report \\
\hline & & In-class activities & $\begin{array}{l}\text { Sections } 4,5,6,7 \text { : Res- } \\
\text { ults, discussion and } \\
\text { conclusion(s) and re- } \\
\text { lated supporting liter- } \\
\text { ature. }\end{array}$ \\
\hline
\end{tabular}

IJFS | October 2020 | Volume 9 | pages 282-294 
pleting the product (Northern Illinois University, 2012). Both were used to assess the students.

\section{Formative}

- Informal observation

The teaching team (culinary science lecturer and culinary arts lecturer) were both present during the kitchen classes each week. They were able to informally observe visually, each individual student's approach to planning and development of the Note by Note dishes over the five weeks of kitchen trials.

- In-class activities comprised four experimental kitchen trials which included physical and chemical tests, informal sensory analysis, and photographing of their dish(es) and, in the last class, a presentation of the final dish.

\section{Summative}

- The academic report

An academic report on the work which was carried out during five assignment classes accounted for $100 \%$ of the total mark for the module. The sections in the report were an (1) introduction, (2) the aim of the assignment; (3) final materials and methods; (4) results; (5) discussion; (6) conclusions, (7) references and (8) a $\log$ book for each of the 5 weeks of the assignment (Table 2). To pass the module, students must have obtained a final mark of $40 \%$, as calculated by formula 1 , in their Note by Note cooking project report.

Formulae

1) Final $\%$ awarded to student

The academic report was marked out of a maximum total of 100

Introduction (10 marks) + aim (5 marks) + final materials and methods (20 marks) + results (20 marks) + discussion (30 marks) + conclusion(s) $(5$ marks $)+$ references $(5$ marks $)+\log$ book $(5$ marks $)=$ a final $\%$ (awarded to the individual student).

Formulae 2 and 3 below were used by the teaching team to evaluate achievement of the learning outcomes of the module.

2) Calculation of Essential Element 1 Introduction (10 marks) + aim (5 marks) + final materials and methods (20 marks) + references ( 5 marks) $+\log$ book ( 5 marks) $=$ Total number $/ 45 \mathrm{X} 100$.

3) Calculation for Essential Element 2

Results (20 marks) + discussion (30 marks) + conclusion(s) (5 marks) + references (5 marks) $=$ Total number $/ 60 \times 100$.

- The International Note by Note contest The dish that most closely matched the entry requirements of the Note by Note International Contest was selected by the teaching team and entered. If chosen for the finals it was further evaluated by an international jury of scientific, culinary and industry experts. Each year the theme is different, for example in 2018 Hervé This (co-founder of Molecular Gastronomy) decided on the theme 'But the crackling is superb' in remembrance of Professor Nicholas Kurti, his fellow molecular gastronomy co-founder. The aim was to create a dish to include the consistencies of crispiness, crunchiness and crackling by following the principles of Note by Note cooking and the originality of the use of compounds would be evaluated (This, 2017). Each proposed dish would be described in a Word file by a recipe giving (1) the ingredients, including quantities, (2) the process and photographs were to be included. The candidates would have to accept that their recipes and pictures could be used (with their name) by the organizers and the partners of the contest.

Evaluation criteria included: 
Evaluation of a project-based Note by Note assignment $\mid 287$

- Feasibility, reproducibility

- Making crisp, crunchy, crackling products

- Originality of the work.

- The use of pure compounds rather than fractions.

- The ingredients and completed dishes should not be toxic.

The complexity of flavour: dishes should have a shape, consistency, odour, taste, trigeminal sensation, and the effect of temperature should be considered.

\subsection{Indirect assessment}

\section{Questionnaire}

The 2016/17 student cohort $(\mathrm{n}=13)$ was asked to answer a series of open-ended questions relating to the MG module (theory lectures, practicals and Note by Note cooking assignment) that they undertook. By using an open-ended questionnaire, emerging data was collected with the primary intent of developing themes from the data (Creswell, 2003). The initial questions were general relating to prior qualifications and any work experience. The following qualitative questions were more detailed, so that participants opinions and observations could be uncovered. Twelve of the thirteen M.Sc. Students (92\% response rate) answered the questionnaire.

\section{Statistical analysis}

In order to determine if there was a significant difference between the results of essential element 1 (formula 2) and essential element 2 (formula 3 ) a t-test was carried out on the assessment results for students who had an overall standard of fair (40-49\%); good (50-59\%); very good (60-69\%) or excellent (70-100\%) using Excel (Microsoft Office 365 ProPlus). The t-test was used to compare means and show whether they were different from each other and how significant those differences were. A correlation coefficient was also calculated using Excel (Microsoft Office 365
ProPlus) to determine the strength of relationships between the individual student grade and the project-based essential elements 1 and 2 .

\section{Results and Discussion}

\subsection{The task and project brief}

At the beginning of the twelve week module, the task and project brief was outlined and discussed with the students in the introductory class of the Advanced Molecular Gastronomy module. As Grant (2002) outlines, the task, guiding question, or driving question explicates what has to be accomplished and embeds the content to be studied. The tasks should be engaging, challenging, and do-able.

By using PBL, students can explore the driving questions by participating in scientific practices and they learn and apply important ideas in the discipline (Krajcik \& Shin, 2014). Through this learning approach the students in TU Dublin were able to critically evaluate questions about food structure, sensory properties, nutrition and toxicity. This approach was underpinned by the fact that Note by Note cooking had a real-world context in that it was contributing to the development of a sustainable food system to feed the expanding world population.

\subsection{Research and Planning}

Students then started researching their dish or dishes. They accessed information from library resources, developed a theme and created drawings and designs of what their dish would look like. They could use the information from the theory lectures and practical classes which were given in weeks 1-7 of the module. It was important when designing the dish to ensure that all sensory attributes would be acceptable. Appropriate sensory tests needed to be identified. The students followed the PBL approach as described by Larmer and Mergendoller (2015) which involved an active, in-depth process over time, generating questions, finding and using resources, asking further questions, and developing their own answers. 
Table 2: Evaluation criteria for the academic report

\begin{tabular}{|c|c|c|c|c|c|}
\hline & \multicolumn{5}{|c|}{ Marking Scheme } \\
\hline Report sections & $\begin{array}{l}\text { Excellent } \\
(>70 \%)\end{array}$ & $\begin{array}{l}\text { Very good } \\
(60-69 \%)\end{array}$ & $\begin{array}{l}\text { Good } \\
(50-59 \%)\end{array}$ & $\begin{array}{l}\text { Fair } \\
(40-49 \%)\end{array}$ & $\begin{array}{l}\text { Fail } \\
(<40 \%)\end{array}$ \\
\hline $\begin{array}{l}\text { 1. Introduction } \\
(10 \text { Marks })\end{array}$ & $\begin{array}{l}\text { Consideration of } \\
\text { a wide range of } \\
\text { relevant literature } \\
\text { sources relating } \\
\text { to molecular } \\
\text { gastronomy, Note } \\
\text { by Note cooking } \\
\text { and the specific } \\
\text { assignment topic. } \\
\text { These sources } \\
\text { were considered } \\
\text { critically and } \\
\text { analysed thor- } \\
\text { oughly. Accurate } \\
\text { referencing }\end{array}$ & $\begin{array}{l}\text { Able to critically } \\
\text { appraise the rel- } \\
\text { evant literature } \\
\text { and theory gained } \\
\text { from a variety of } \\
\text { sources. Refer- } \\
\text { encing is mainly } \\
\text { accurate. }\end{array}$ & $\begin{array}{l}\text { Clear evidence } \\
\text { and application } \\
\text { of readings which } \\
\text { are relevant to the } \\
\text { subject. Refer- } \\
\text { encing is mainly } \\
\text { accurate. }\end{array}$ & $\begin{array}{l}\text { Literature is } \\
\text { presented uncrit- } \\
\text { ically, in a purely } \\
\text { descriptive way } \\
\text { and indicates } \\
\text { limitations of } \\
\text { understanding. }\end{array}$ & $\begin{array}{l}\text { Published docu- } \\
\text { ments summar- } \\
\text { ised, but not } \\
\text { linked in any } \\
\text { effective way to } \\
\text { the aim(s) of the } \\
\text { assignment. }\end{array}$ \\
\hline $\begin{array}{l}\text { 2. Aim of the } \\
\text { assignment } \\
\text { Marks })\end{array}$ & $\begin{array}{l}\text { Clear concise and } \\
\text { coherent state- } \\
\text { ment of what is to } \\
\text { be achieved. }\end{array}$ & $\begin{array}{l}\text { Clear statement } \\
\text { that indicates } \\
\text { achievability. }\end{array}$ & $\begin{array}{l}\operatorname{Aim}(\mathrm{s}) \text { stated, but } \\
\text { either too many } \\
\text { or is not concise } \\
\text { enough. }\end{array}$ & $\begin{array}{l}\text { Aim(s) stated but } \\
\text { unclear. }\end{array}$ & $\begin{array}{l}\text { The aim(s) does } \\
\text { not link to the } \\
\text { work carried out. }\end{array}$ \\
\hline $\begin{array}{l}\text { 3. Final Materials } \\
\text { and Methods ( } 20 \\
\text { Marks) }\end{array}$ & $\begin{array}{l}\text { Materials and } \\
\text { methods clearly } \\
\text { described. De- } \\
\text { tails of makes } \\
\text { and models of } \\
\text { all equipment } \\
\text { provided. Ac- } \\
\text { curate and clear } \\
\text { recipes for all } \\
\text { elements of a } \\
\text { dish and/or cock- } \\
\text { tail. Accurate } \\
\text { referencing. }\end{array}$ & $\begin{array}{l}\text { Good description } \\
\text { of materials and } \\
\text { methods. Recipes } \\
\text { included. Refer- } \\
\text { encing mainly ac- } \\
\text { curate. }\end{array}$ & $\begin{array}{l}\text { Adequate descrip- } \\
\text { tion of the mater- } \\
\text { ials and methods } \\
\text { used. Referencing } \\
\text { is mainly accurate }\end{array}$ & $\begin{array}{l}\text { Vague and with } \\
\text { some gaps in } \\
\text { the materials. } \\
\text { Methods are } \\
\text { not presented in } \\
\text { a logical order } \\
\text { but are partially } \\
\text { related to the } \\
\text { project aim(s). } \\
\text { Some attempt at } \\
\text { referencing. }\end{array}$ & $\begin{array}{l}\text { Incomplete or no } \\
\text { list of materials } \\
\text { used. Methods, } \\
\text { handled incom- } \\
\text { pletely, with little } \\
\text { evidence of link to } \\
\text { aim(s). Inaccur- } \\
\text { ate or no recipes } \\
\text { included. }\end{array}$ \\
\hline $\begin{array}{l}\text { 4. Results (20 } \\
\text { Marks) }\end{array}$ & $\begin{array}{l}\text { Relevant res- } \\
\text { ults clearly set } \\
\text { out. All figures, } \\
\text { charts (sensory } \\
\text { and spider plots), } \\
\text { tables, photos } \\
\text { etc. are correctly } \\
\text { and uniformly } \\
\text { labelled. Photos } \\
(300 \text { dpi). }\end{array}$ & $\begin{array}{l}\text { Results are well } \\
\text { presented. All } \\
\text { relevant figures, } \\
\text { charts, tables, } \\
\text { photos etc. are } \\
\text { included. }\end{array}$ & $\begin{array}{l}\text { Results are ad- } \\
\text { equately presen- } \\
\text { ted. All relevant } \\
\text { figures, charts, } \\
\text { tables, photos etc. } \\
\text { are included. }\end{array}$ & $\begin{array}{l}\text { Results are not } \\
\text { presented in a } \\
\text { logical order. } \\
\text { Inaccuracies in la- } \\
\text { belling of figures, } \\
\text { charts, tables, } \\
\text { photos etc. }\end{array}$ & $\begin{array}{l}\text { Incomplete set } \\
\text { of results with } \\
\text { inaccurate or } \\
\text { no labelling of } \\
\text { figures, charts, } \\
\text { tables, photos } \\
\text { etc. No clear link } \\
\text { between results } \\
\text { and assignment } \\
\text { aim(s). }\end{array}$ \\
\hline $\begin{array}{l}\text { 5. Discussion ( } 30 \\
\text { Marks) }\end{array}$ & $\begin{array}{l}\text { The results are } \\
\text { compellingly } \\
\text { supported by } \\
\text { appropriate evid- } \\
\text { ence. In depth } \\
\text { discussion and } \\
\text { exploration of the } \\
\text { driving questions. }\end{array}$ & $\begin{array}{l}\text { The results are } \\
\text { clearly supported } \\
\text { by appropriate } \\
\text { evidence. }\end{array}$ & $\begin{array}{l}\text { The application of } \\
\text { analysis and valid- } \\
\text { ity of results and } \\
\text { evidence are indic- } \\
\text { ated }\end{array}$ & $\begin{array}{l}\text { Results are re- } \\
\text { peated but very } \\
\text { little attempt of } \\
\text { a discussion of } \\
\text { their relevance is } \\
\text { presented. }\end{array}$ & $\begin{array}{l}\text { Findings bear } \\
\text { little or no rela- } \\
\text { tion to evidence. }\end{array}$ \\
\hline
\end{tabular}


Evaluation of a project-based Note by Note assignment $\mid 289$

Table 2: Evaluation criteria for the academic report (cont.)

\begin{tabular}{|c|c|c|c|c|c|}
\hline & \multicolumn{5}{|c|}{ Marking Scheme } \\
\hline Report sections & $\begin{array}{l}\text { Excellent } \\
(>70 \%)\end{array}$ & $\begin{array}{l}\text { Very good } \\
(60-69 \%)\end{array}$ & $\begin{array}{l}\text { Good } \\
(50-59 \%)\end{array}$ & $\begin{array}{l}\text { Fair } \\
(40-49 \%)\end{array}$ & $\begin{array}{l}\text { Fail } \\
(<40 \%)\end{array}$ \\
\hline $\begin{array}{l}\text { 6. Conclusion(s) } \\
(5 \text { Marks })\end{array}$ & $\begin{array}{l}\text { Conclusions are } \\
\text { clearly and suc- } \\
\text { cinctly stated and } \\
\text { are relevant to the } \\
\text { aim(s). They are } \\
\text { linked to results } \\
\text { and discussion. }\end{array}$ & $\begin{array}{l}\text { Conclusions } \\
\text { stated which are } \\
\text { relevant to the } \\
\text { aim(s) and linked } \\
\text { to results and } \\
\text { discussion. }\end{array}$ & $\begin{array}{l}\text { Attempts to draw } \\
\text { conclusions from } \\
\text { results are not en- } \\
\text { tirely convincing. }\end{array}$ & $\begin{array}{l}\text { Conclusions are } \\
\text { weak and do not } \\
\text { really follow from } \\
\text { the results and } \\
\text { discussion. }\end{array}$ & $\begin{array}{l}\text { No detectable con- } \\
\text { clusions }\end{array}$ \\
\hline $\begin{array}{l}\text { 7. References (5 } \\
\text { Marks) }\end{array}$ & $\begin{array}{l}\text { Complete and ac- } \\
\text { curate referencing } \\
\text { in Harvard format }\end{array}$ & $\begin{array}{l}\text { Referencing is } \\
\text { mainly accurate. }\end{array}$ & $\begin{array}{l}\text { Referencing is } \\
\text { mainly accurate. }\end{array}$ & $\begin{array}{l}\text { Some attempt at } \\
\text { referencing. }\end{array}$ & $\begin{array}{l}\text { Incomplete, un- } \\
\text { systematic or } \\
\text { norrefence } \\
\text { list. Referencing } \\
\text { errors. }\end{array}$ \\
\hline $\begin{array}{l}\text { 8. Log book (5 } \\
\text { Marks) }\end{array}$ & $\begin{array}{l}\text { All } 5 \text { weeks work } \\
\text { to be included. } \\
\text { Written in correct } \\
\text { format. }\end{array}$ & $\begin{array}{l}\text { All } 5 \text { weeks work } \\
\text { is included and it } \\
\text { is written in the } \\
\text { correct format but } \\
\text { more detail is re- } \\
\text { quired }\end{array}$ & $\begin{array}{l}\text { All } 5 \text { weeks work is } \\
\text { included and it is } \\
\text { written in the cor- } \\
\text { rect format but a } \\
\text { lot more detail is } \\
\text { required }\end{array}$ & $\begin{array}{l}\text { Not all work is in- } \\
\text { cluded. Not al- } \\
\text { ways in a logical } \\
\text { sequence. Lack of } \\
\text { detail. }\end{array}$ & $\begin{array}{l}\text { Incomplete and } \\
\text { not written in the } \\
\text { correct format. }\end{array}$ \\
\hline
\end{tabular}

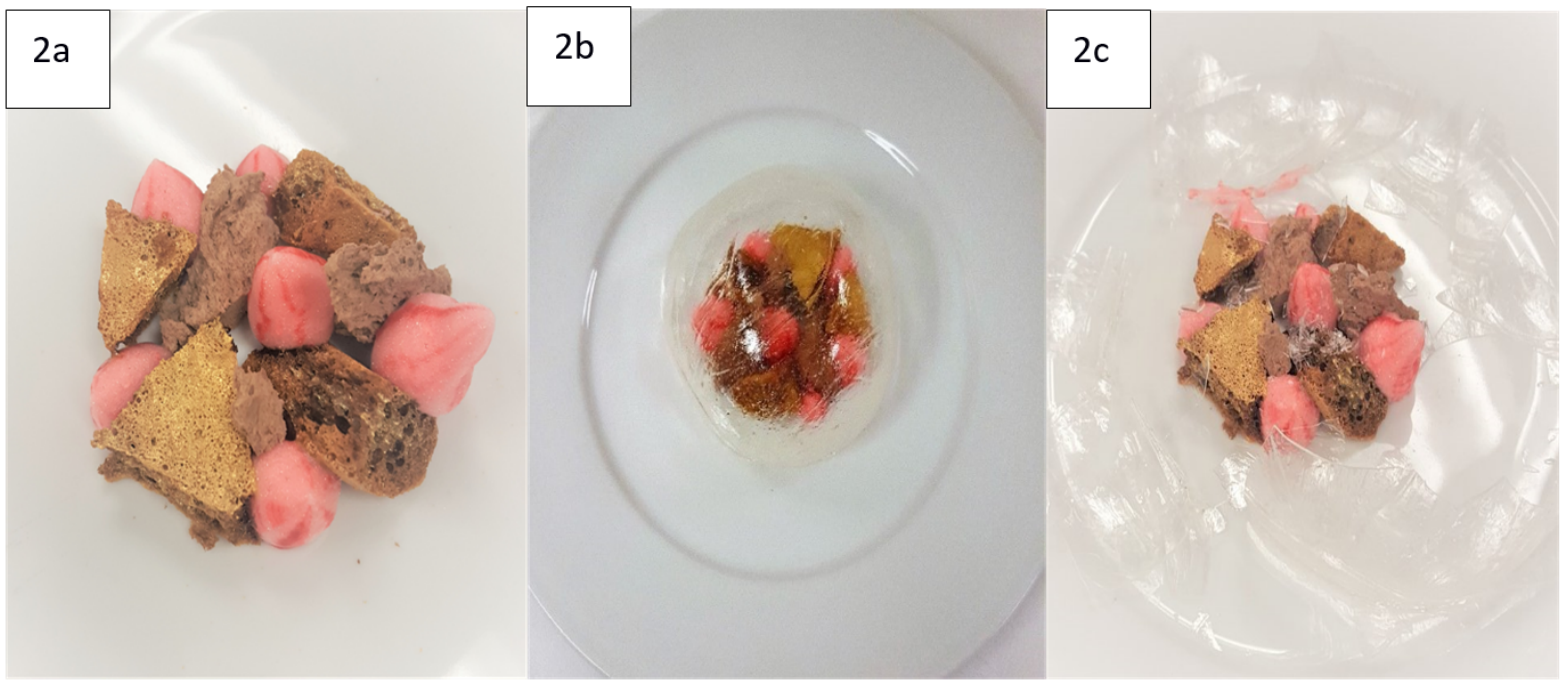

Figure 2: 'A Reminisence of a Black Forest Gateaux' (2018). Dish by Ruth Kelly. Theme: Crispiness, Crackling, Crunchiness. Figure 2a shows the dish without the isomalt dome. Figure 2b shows the dish covered with the intact isomalt dome. In Figure 2c the diner shatters the dome with a spoon and flavoured smoke is released, which gives the impression of a misty forest atmosphere 


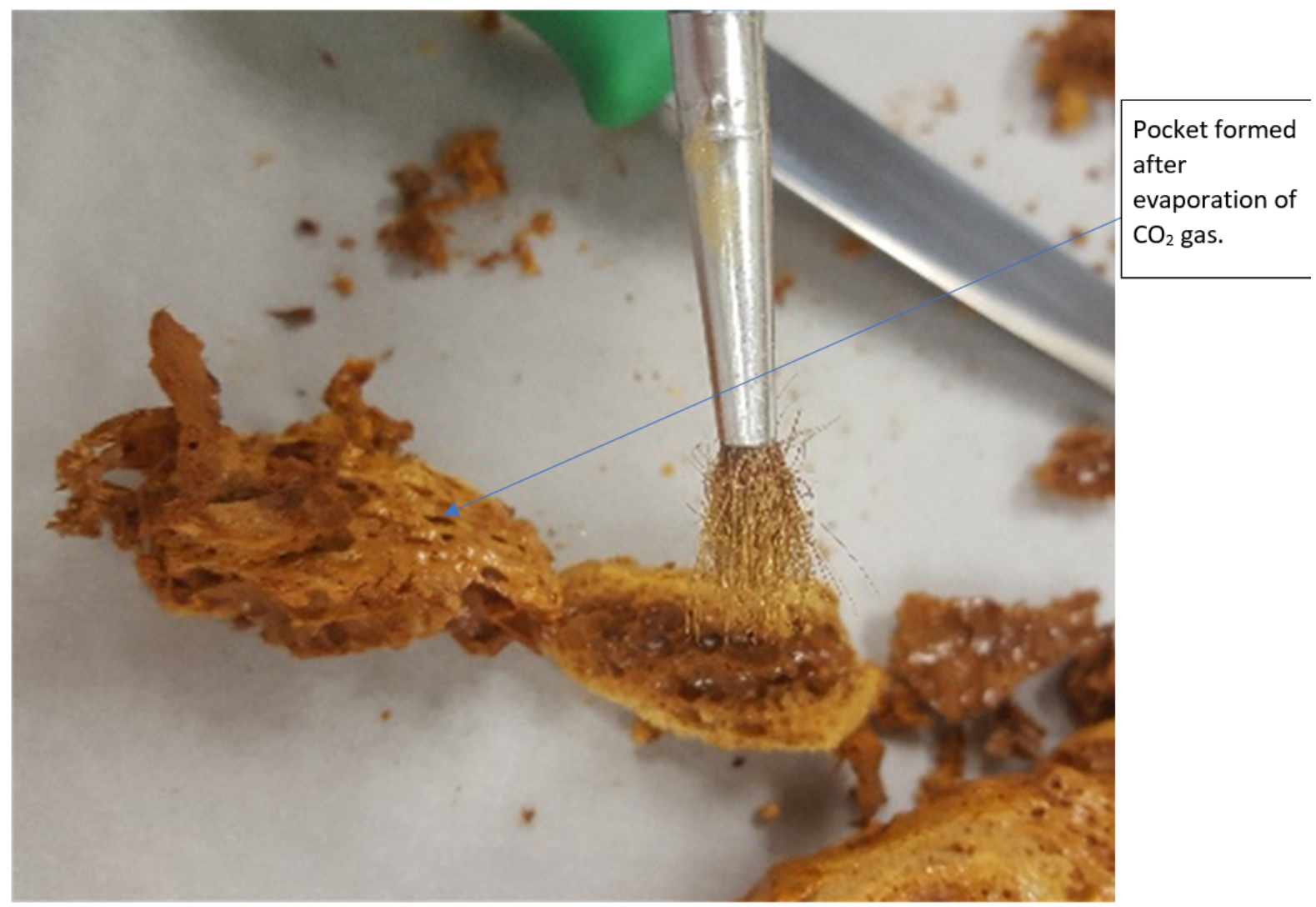

Figure 3: Gold colouring being applied to cut honeycomb - Image: Ruth Kelly (2018).

\subsection{Kitchen trials and improving recipes}

In the last five weeks of the twelve week module, the students carried out three hour kitchen classes once a week. The time planning for these classes was done during the first seven weeks of the module. Ingredients and equipment needed to be ordered a minimum of two weeks in advance of starting the kitchen work. During the kitchen trials, the students kept a $\log$ book and recorded information about ingredients and equipment, their progress and recommendations for the next week. Grant (2002) notes that the process and investigation stage of project-based learning includes the steps necessary to complete the task or answer the guiding or driving question. The process should include activities that require higher-level and critical thinking skills, such as analysis, synthesis, and evaluation of information. For example in 2018, it was necessary for the students to explore what was meant by crispiness, crunchiness and crackling and to design a dish with food structures that would give the sensation of these consistencies. This was not an easy task and the student who best met the challenge developed these elements in her dish. An isomalt ((3R,4R,5R)-6-[(2S,3R,4S,5S,6R)3,4,5-trihydroxy-6-(hydroxymethyl)oxan-2-

yl] oxyhexane-1,2,3,4,5-pentol) dome was created following testing of thicknesses, temperatures, concentrations of ingredients and moisture content. The goal was to create a crisp and brittle texture (Figures 2a, 2b and 2c). For the crunchy and crackling element, she developed a honeycomb which was made by producing $\mathrm{CO}_{2}$ gas from sodium hydrogen carbonate (Figure 3). 
The gas bubbles evaporated during heating and formed pockets, of approximately 1 to $1.5 \mathrm{~mm}$ diameter on average, which were set in place by sugar. The structure collapsed in the mouth when broken with the teeth. This resulted in crunching and crackling sounds while eating. In this project, scientific practices included physical and chemical testing and sensory analysis testing (informal) each week with fellow classmates. Students discussed their ongoing project with lecturing staff (culinary science and culinary arts) and gained formative feedback to help them improve their recipes both scientifically and artistically.

\subsection{Presentation of the $\operatorname{dish}(\mathrm{es})$}

In the final class the students presented their dish(es) for sensorial valuation by the lecturing staff. They took photographs to include in their TU Dublin project and also for the Note by Note competition. An example of a recent winning dish (joint first place in the student category) is shown in Figures 2a, 2b and 2c.

\subsection{Assessment and evaluation of the project-based learning assignment}

The aim of the Advanced Molecular Gastronomy module was to allow the learner to gain an indepth understanding of the principles and applications of molecular gastronomy at an advanced level. The learning outcomes of the module are outlined in Table 1. According to Nusche (2008), learning outcomes refer to the personal changes or benefits that follow as a result of learning. Such changes or benefits can be measured in terms of abilities or achievements. Since 2012 until the present time, $92 \%$ of all students passed the module. Results ranged from $40 \%$ (pass standard) to $76 \%$ (excellent standard). However, the individual student percentage mark did not provide information on the level of attainment for each of the two essential elements of the project-based assignment. Dahm (2014) crafted detailed rubrics for each of the essential elements in his courses and mapped student outcomes to project elements. He then compiled the data in Excel which allowed a summary of student performance with respect to each of the programme's student outcomes to be automatically generated. A similar rubric with defined evaluation criteria was used (Table 2) to provide a detailed insight into the level of achievement of the essential elements and corresponding learning outcomes.

Figure 4 shows the results for overall totals and for corresponding essential elements from a representative sample of individual marks in the fair, good, very good and excellent categories. It was carried out for recent student cohorts (2016/17, $2017 / 18$ and 2018/19) and revealed that overall students achieved a significantly higher percentage for essential element 1 compared to essential element $2(\mathrm{P} \leq 0.01)$. The exceptions were results in the excellent category $(>70 \%)$ where essential element 2 scored higher than 1. Correlation coefficients for the project-based essential elements and the individual student grades were 0.92 and 0.97 for essential elements 1 and 2 respectively, showing that there was a good relationship between the individual grade and each of the essential elements.

\subsection{International assessment}

The student who was selected by the teaching team to represent their class at the international Note by Note contest had not always achieved the highest individual grade in the class but did create a dish that best matched the criteria for the contest. In doing so they demonstrated what they had learnt by creating a product that was presented to people beyond the classroom (Larmer \& Mergendoller, 2015; Thomas, 2000). All of the representative dishes which were entered by TU Dublin into each of the six international Note by Note contests (20132018) were awarded first place in the student category of the contest.

\subsection{Questionnaire}

The students were asked if they had studied science subjects before and if so at what level. There is no entry requirement for applicants to have previously studied science. However, the 


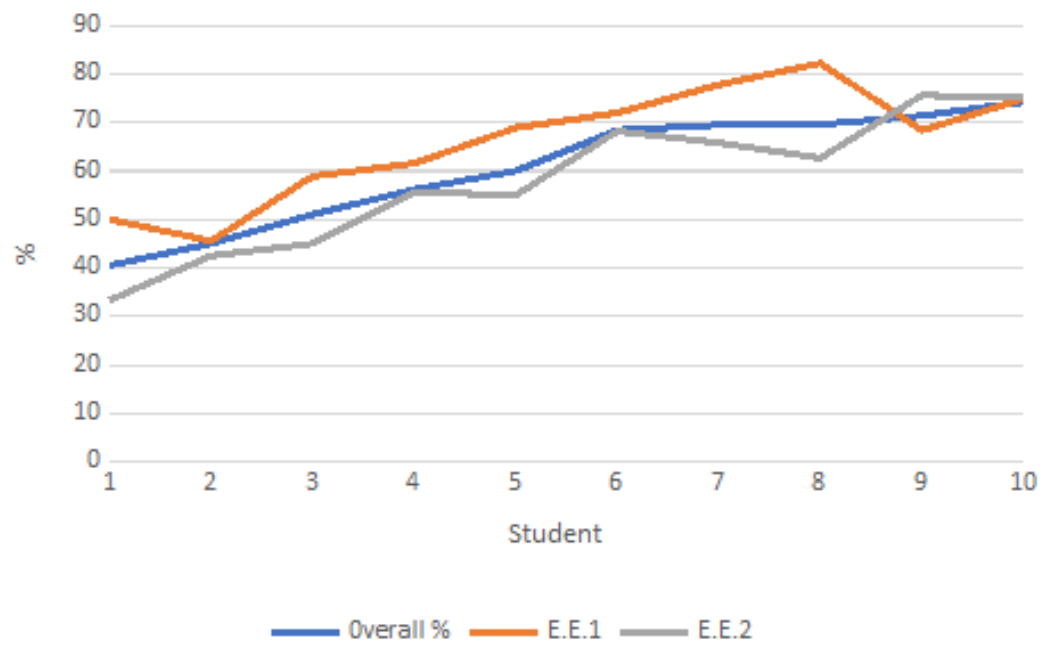

Figure 4: Individual overall marks and individual essential element (E.E.) 1 and 2 marks.

Table 3: Student Evaluation of the Module

\begin{tabular}{|c|c|}
\hline $\begin{array}{l}\text { Question to stu- } \\
\text { dents }\end{array}$ & Collation of responses \\
\hline $\begin{array}{l}\text { Highlights of the MG } \\
\text { module }\end{array}$ & $\begin{array}{l}\text { The main highlights of the postgraduate module were the kitchen } \\
\text { practicals including the demonstration of Note by Note cooking and } \\
\text { the use of liquid nitrogen. They liked that they had the freedom to } \\
\text { experiment. The students also enjoyed learning about Note by Note } \\
\text { cooking and Note by Note cuisine as well as new culinary concepts }\end{array}$ \\
\hline $\begin{array}{l}\text { Improvements that can } \\
\text { be made to the mod- } \\
\text { ules }\end{array}$ & $\begin{array}{l}\text { Many of the postgraduate students would have liked more time in the } \\
\text { kitchen and more time allocated to experimenting with Note by Note } \\
\text { cooking in the kitchen as well as more time allocated to the Note by } \\
\text { Note project. }\end{array}$ \\
\hline $\begin{array}{l}\text { Theory lectures before } \\
\text { the practical kitchen } \\
\text { classes }\end{array}$ & $\begin{array}{l}\text { The most effective teaching strategy was to have theory lectures fol- } \\
\text { lowed by the application of knowledge in practical kitchen classes. } \\
\text { The M.Sc. students found the theory classes very beneficial and im- } \\
\text { portant in helping them to understand the properties and chemical } \\
\text { reactions of the compounds that they would use in Note by Note } \\
\text { cooking. A couple of students suggested condensing the lectures and } \\
\text { giving more time in the kitchen. }\end{array}$ \\
\hline Team teaching & $\begin{array}{l}\text { All the postgraduate respondents were unanimous in their comments } \\
\text { that the team teaching was very important and helpful. Half of the } \\
\text { postgraduate students, those who had not previously worked in in- } \\
\text { dustrial kitchens, commented that they learnt from the other students } \\
\text { about working in a kitchen environment and food presentation skills. }\end{array}$ \\
\hline $\begin{array}{l}\text { Project-based learning } \\
\text { assignment }\end{array}$ & $\begin{array}{l}\text { The postgraduate students got a better understanding of the com- } \\
\text { pounds and e-numbers and their functions and culinary uses. They } \\
\text { also learnt about Note by Note cooking, as well as researching, inde- } \\
\text { pendent thinking and perseverance. }\end{array}$ \\
\hline
\end{tabular}

IJFS | October 2020 | Volume $9 \mid$ pages 282-294 
responses from the participants of the MG module showed that some had studied science subjects albeit at various levels. These included final year school biology, and culinary science, microbiology, biochemistry, food safety, biology, chemistry, physics and nutrition at higher education level (see Table 3).

\section{Conclusion}

By using a project-based Note by Note cooking exercise, $92 \%$ of students achieved the learning outcomes of the module. A detailed evaluation of the individual assessment grades however revealed that most of the students were better at finding and using resources, asking further questions and developing their own answers than analysing, synthesising and evaluating information. In future students should carry out a more indepth analysis, synthesis and evaluation of information.

Students who were chosen to represent their class at the international contest in Paris did not always have the highest grade in their class but were deemed to have produced the dish which matched the requirements of the competition the closest. This was endorsed by their success, winning first place in the student category each year since the contest started six years earlier.

\section{Acknowledgements}

Thank you to La Rousse Foods, Ireland for sponsoring student travel to the contest.

\section{References}

Bell, S. (2010). Project-based learning for the 21st century: Skills for the future. The Clearing House, 83, 39-43. doi:10.1080/ 00098650903505415

Boaler, J. (1999). Mathematics for the moment, or the millennium. Education Week, $17(29), 30-34$
Breslow, L. (2007). Methods of measuring learning outcomes and value added teaching and learning laboratory, massachusetts institute of technology. Retrieved from http:// tll.mit.edu/sites / default / files / guidelines / a-e-tools-methods-of-measuring-learningoutcomes-grid-2.pdf

Burke, R. \& Danaher, P. (2018). Interdisciplinary teaching and learning within molecular gastronomy education: Does it benefit students? International Journal of Molecular Gastronomy, 1, 1-12. Retrieved from http://www.agroparistech.fr/EducationalApplications - of - Molecular - Gastronomy . html

Burke, R. \& Danaher, P. (2016). Note by note: A new revolution in cooking. Retrieved from http: / / arrow.dit.ie/cgi/viewcontent.cgi? article $=1060 \&$ context $=$ dgs

Burke, R., This, H. \& Kelly, A. L. (2016). Molecular gastronomy. In Reference module in food science. doi:10 . 1016 / B978-0-08100596-5.03302-3

Burke, R., Danaher, P. \& Traynor, M. (2012). The development of molecular gastronomy as a subject discipline at the dublin institute of technology. Retrieved from http:// arrow . dit.ie/cgi/viewcontent. cgi? article= $1012 \% 5$ C\&context $=\mathrm{dgs}$

Condliffe, B., Visher, M. G., Bangser, M. R., Drohojowska, S. \& Saco, L. (2016). Project-based learning: A literature review. New York, Ny: Mdrc. Retrieved from https: / / www . mdrc . org / sites / default / files / Project-Based_Learning-LitRev_Final.pdf

Creswell, J. W. (2003). Research design: qualitative, quantitative, and mixed methods approaches. Thousand Oaks, Sage.

Dahm, K. (2014). Combining the tasks of grading individual assignments and assessing program outcomes in project-based courses. Journal of STEM Education, 15(1), 20-29.

Donnelly, R. \& Fitzmaurice, M. (2005). Collaborative project-based learning and problembased learning in higher education: A consideration of tutor and student role in learner-focused strategies. Retrieved from https:// arrow.dit.ie/cgi/viewcontent.cgi? referer $=\&$ httpsredir $=1 \&$ article $=1006 \&$ context $=$ ltcbk 
Doppelt, Y. (2003). Implementation and assessment of project-based learning in a flexible environment. International Journal of Technology and Design Education, 13, 255272. doi:10.1023/A:1026125427344

Grant, M. M. (2002). Getting a grip on projectbased learning: Theory, cases and recommendations. Meridian: A middle school computer technologies journal, 5(1), 83.

Krajcik, J. S. \& Shin, N. (2014). The cambridge handbook of the learning sciences. In R. K. Sawyer (Ed.), (Chap. Project-based learning, pp. 275-297). New York, NY: Cambridge University Press.

Larmer, J. \& Mergendoller, J. R. (2015). Gold standard pbl: Essential project design elements [web log post]. Buck Institute for Education. Retrieved from www.bie.org

Mc Donnell, C., O’Connor, C. \& Seery, M. K. (2007). Developing practical chemistry skills by means of student-driven problem based learning mini-projects. Chemistry Education Research and Practice, 8(2), 130-139.

Northern Illinois University. (2012). In Instructional guide for university faculty and teaching assistants. Retrieved from http : //www.niu.edu/facdev/resources/guide

Nusche, D. (2008). Assessment of learning outcomes in higher education: A comparative review of selected practices. OECD, Directorate for Education, OECD Education Working Papers.

Shewfelt, R. (2012). Becoming a food scientist. (pp. 25-32). doi:10.1007/978-1-4614-32999_3

Spronken-Smith, R. \& Walker, R. (2010). Can inquiry-based learning strengthen the links between teaching and disciplinary research? Studies in Higher Education, 35(6), 723-740.

This, H. (2014). Note by note cooking: : The Future of Food. Translated from French by Malcolm DeBevoise. New York: Columbia University Press.

This, H. (2017). International contest for note by note cooking $n^{\circ} 6$. Retrieved from http: //www2.agroparistech.fr/IMG/pdf/annc ccnan_6_sans_en.pdf
Thomas, J. W. (2000). A review of research on project-based learning. San Rafael, $C A$ : The Autodesk Foundation. Retrieved from http://www.\%20bobpearlman.org/Best\% 20Practices/PBL\%20Research.pdf 